\title{
THE INFLUENCE OF HIGH TEMPERATURES ON THE HUMAN BODY, ESPECIALLY WITH REGARD TO HEAT-STROKE. ${ }^{1}$
}

\author{
By Harvey Suttos, M.D., Ch.B.(Melb.), B.Sc.(Oxon.), Rhodes \\ Scholar, New College, Oxford.
}

From the Department of Pathology, University of Oxford.

$$
\text { (Plates VII.-X.) }
$$

Is the investigation of the particular association of high temperature and altered metabolism which we call "fever," one of the greatest problems has been, and still is, the accurate definition and relative importance of the parts played by such factors as inanition, toxcemia, and hyperpyrexia. Help has been sought for the estimation of the effects of high temperature on the body from the knowledge gained in

- researches on certain pyrexial conditions allied to fever. Heat-stroke in particular is especially fitted for the proper understanding of this estimation, because in it a condition of high temperature may be produced in a previously normal individual by varying the external atmospheric conditions in a perfectly controllable way while toxic influences are completely eiininated. For though increased production of heat by muscular work does assist in the upsetting of the balance of heat regulation, yet the rise of body temperature in heat-stroke depends, essentially, on the external temperature and the degree of humidity of the surrounding air, and will occur when these reach a certain point even though muscular action is carefully avoided.

In the investigation of heat-stroke it was necessary to clear the way of certain fallicies relating to the origin of the condition.

First, it was realised that the previous term "sunstroke" was a misnomer, for in a large majority of cases the direct action of the sun's rays is absent, and in any case is responsible for only a small percentage of the resulting cases. External heat, then, was found to have a marked influence only when associated with a certain degree of atmospheric humidity, and later the importance of a high reading of the wet-bulb thermometer was definitely proved. The apparent epidemic character of the occurrence of heat-stroke cases has led some investigators (e.g. Sambon $\left(1898^{4}\right)$ ) to the hypothesis of a specific germ, but it may be accepted as indisputable that a high wet-bulb temperature is the essential factor in the production of heat-stroke. Conclusive evidence on

1 Received June 27, 1908. 
these points has been furnished by Haldane $\left(1905^{1}\right)$, L. Rogers $\left(1907^{2}\right)$, and also by Pembrey $\left(1902{ }^{8}\right)$.

The ain of the present experiments was to investigate the relation between rise of body temperature and metabolism as indicated by the respiratory exchange. Many investigators have performed overheating experiments on animals. Pfliger $\left(1877^{5}\right)$ and his associates showed increase of oxidation even in mammals with rise of body temperature; but little work has been carried out on the human subject.

Riibner $\left(1895^{10}\right)$, in hot baths of short duration,- - not greatly affecting the heat balance,- - found increased amounts of $\mathrm{O}_{2}$ and $\mathrm{CO}_{2}$ and a slight increase of the respiratory quotient. Winternitz $\left(1899^{6}\right)$, following up this work and using hot baths of about forty-five minutes' duration, came to the following conclusions. A minimal rate of metabolism is reached by the body at $30^{\circ} \mathrm{C}$. ; no further drop of metabolism occurs with exposure to greater heat, but a definite increase of oxygen and carbonic acid gas exchange,- the two increasing together so that the respiratory quotient is only slightly greater : the oxygen consumption is increased more thun in fever ( 20 per cent.), without any direct respiratory effort to account for the rise. These experiments, however, were of quite short duration, and the rectal temperature was not carefully followed. ${ }^{1}$

In Linser and Schmid's (7) patients the oxygen consumption increased by 100 per cent., but the respiratory quotient sank to 0.429 . Such a reduction of quotient argues some fallacy in their methods of observation. The patients suffered from ichthyosis, and, owing to their inability to sweat, reacted to high dry-air temperatures in the same way as healthy persons do to high wet-bulb temperatures.

$\mathrm{My}$ experiments show that there is a distinct tendency to parallelisw in the rise of body temperature and the increase in respiratory exchange. The parallelism is best shown in those experiments where the height of wet-bulb temperature remained most constant. They justify the application to man himself of Pfluger's theory for animals. In other words, human metabolism increases with rise of internal temperature of the body, and in this way is comparable with any simple chemical reaction.

The experiments were conducted by the kindness of Dr. Ritchie in a room in the Pathological Laboratory at Oxford. The room was heated by open gas flames, but ventilation from chinks, etc., was so free and the resulting loss of heat from the room itself so great that a sufficiently high temperature $\left(33^{\circ} \mathrm{C}\right.$. wet bulb) could only be obtained on the hottest days in summer $\left(20^{\circ} \mathrm{C}\right.$. or over). The air was nearly saturated with moisture by means of a boiling kettle of water.

The respiratory gases were collected by means of the Haldane respiratory apparatus, which is designed on the general principle used by Zuntz (1904) and other investigators, but with certain modifications. A leaden pipe ( $1 \mathrm{in}$. in diameter) led into the room from the exterior of the building, and connected by a long piece of stiff rubber hose ( 1 in. in diameter and fitted with a lateral mouth piece) to a wet neter, from which another pipe led away to an electrically driven rotary exhaust fan in the basement of the building (see Plate VII. Fig. 1). A current of air from the exterior could thus be maintained at a definite rate through the tubing, and constant conditions as to respiratory air supply obtainel. Into a hole made into the hose close to the meter, and about

1 Pembrey $\left(1902^{3}\right)$ has shown the importance of the rectal tenperature as a correct indicator of the lody temperature, and the fallacies which have arisen from insccurate methods of temperature observation. 
six feet from the mouthpiece, the end of a glass collecting bulb with two-way taps could be tightly fitted. The other end of the bulb was connected by a long piece of stout rubber pressure tubing in U-shape to a glass vessel containing mercury. By this latter arrangement a difference in level of the mercury in the two limbs of the siphon of about 36 in., i.e. more than the barometric height, allowed the bulb to be emptied of mercury at a constant rate during the collection of a sample of gas.

\section{Method of Experimeit.}

The subject (æt. 25 year, and weighing 80 kilos.) entered the hot room stripped to the waist, weuring only cricketing flannels, socks, and light shoes. Temperatures were recorded by ordinary half-minute clinical thermometers inserted for at least three minutes in the mouth and rectum. They together with the wet and dry-bulb thermometers were carefully corrected by comparison with a standardised $\mathrm{Kew}$ themometer. In order to eliminate the effect of previous meals, and so obtain as uniform conditions of metabolism as possible, neither food nor drink was taken after the regular college dinner at 7 p.m. the evening before the experiment, the hot room being entered between midday and 2 p.m., i.e. after a fast of seventeen to twenty hours. Fasting had the further advantage of providing a low respiratory quotient, so rendering any rise of quotient the more casily noticenblo (Pembrey and Spriggs (1894 $\left.{ }^{8}\right)$ ).

In collecting a sample the subject reclinet in a deck chair in a perfectly comfortable position, so that the mouthpiece could be used with the heal resting on a cushion on the back of the chair. After breathing through the mouthpiece for 4 to 5 minutes the taps of the glass bulb (then full of mercury and connected with the rubber hose) were turned, and the bulb allowed to nearly empty itself. The rate of emptying by means of the device nentioned was practically constant during the collection of each sample, and took about three minutes altogether. Before the bulb was quite empty the taps were closed, and the subject then discardel the mouthpiece.

The sample thus collected was later analysed by means of Haldane's gas analysis apparatus. From the results of at least three analyses the percentage of carbon dioxide and of oxygen in the sample was estimated. The reading of the neter before and after each sample gave the rate of air current ; and from the combined data the amount of the respiratory exchange in cubic centimetres (at $0^{\circ} \mathrm{C}$. and $760 \mathrm{~mm}$. mercury pressure) of dry oxygen and carbon dioxide could be estimated. In making the calculation allowance was made for the diminution in volume of the dry expired air when the respiratory quotient was less than unity.

Although objections have been made to the dependence placed on results given by this method (Zuntz (1896 18)), still with experience in the technique, and using proper precautions against the introduction of certain factors which produce fallacious resulte, such objections can be overcome and reliable and constant results obtained. Care was taken to adopt a comfortable posture in breathing and no mask was used, the nose being compressed when neccssary by the fingers. A little experience, sometimes aided by the detachment of mind gained in reading a book, easily onabled one to breathe normally without conscious effort or want of offort. Haldane and Priestley (1905 ${ }^{9}$ ) have shown in their experiments on alveolar $\mathrm{CO}_{2}$ that, as long as breathing is not forcerl in character, increased frequency and increased depth compensate each other. Care was also taken to ensure a constant rate of emptying of the glass collecting bulbs. The method described above appears to be both simpler and less liable to error than the discontinuoux method of collecting the sample in the apparatus devised by Zuntz $\left(1901{ }^{19}, 1904{ }^{20}\right)$. The sample is of course diluted with pure air, but this is compensated for by the more accurate method of analysis employed. 


\section{Effects of Overheating on Man.}

The general condition of the subject, and especially the mental phenomena, seem to bear a close relationship to the rise of internal body temperature. In later experiments a tolerable guess as to its height could thus be made. The marked sensation of heat felt on entering the room ( $35^{\circ}$ wet bulb) soon passed off on resting quietly, and was replaced on the occurrence of free sweating by a relaxing and not unpleasant sensation of warmth. Dilatation of the superficial vessels and relaxation of muscular tone was marked, and still more marked was the sensation of sleepiness, which often became quite overpowering. This condition, however, only existed during the stage of compensation when the internal temperature was stationary or only beginning to rise gradually. The organism seems to reduce its energy requirements to a minimum, and so muscular and mental effort are practically abolished. This state lasted during these experiments for only half an hour or so, for as soon as the rise of temperature became at all definite $\left(99^{\circ} \cdot 5 \mathrm{~F}\right.$. rectal) this was associated with quite another set of sensations. Sleepiness disappeared, and the complete muscular idleness passed off and was replaced by a marked and increasing irritability. The change from drowsiness to wakefulness and irritability was comparatively abrupt, and occurred quite constantly at about $99^{\circ} \cdot 5 \mathrm{~F}$. (rectal) $\left[37^{\circ} \cdot 5 \mathrm{C}\right.$.]. Once the rise of rectal temperature was fairly marked $\left(2^{\circ}-3^{\circ} \mathrm{F}\right.$. $\left[1^{\circ} \cdot 1-1^{\circ} \cdot 66 \mathrm{C}.\right]$ or $101^{\circ}-102^{\circ} \mathrm{F}$. $\left[38^{\circ} \cdot 36-\right.$ $38^{\circ} .9$ C.] rectal temperature) the continuance of any employment, such as reading a book or sitting in one position, became intensely tiresome. For example, the attempt to learn by heart a short vocabulary of German words proved a complete failure. To remain at rest required a marked effort of will, and the only approach to comfort was obtained by slowly lounging about so as to continuously change one's position. Later on, when the rectal temperature rose over $103^{\circ} \mathrm{F} .\left(39^{\circ} 1 \mathrm{C}\right.$ ) any irritation, however slight, became not merely tiresome, but actually annoying and trying to one's temper. This irritability - a preliminary sign of early exhaustion of the central nervous system-is thus closely associated with rise in body temperature. Immediate relief was felt on reaching the cool external temperature, and this was accompanied by a rapid fall in internal temperature, $2^{\circ}-3^{\circ} \mathrm{F} .\left(1^{\circ} \cdot 1-1^{\circ} \cdot 6 \mathrm{C}\right.$. $)$ in ten to fifteen minutes.

Beyond a certain degree of slackness on the evening after the experiment and the next day, practically no after effects were noticeable, except a distinct feeling of increased tone on the second day after. The rectal and mouth temperatures were observed at the beginning and at intervals throughout the experiment, particularly when a sample of respiratory gases was taken. On entering the hot room a rapid rise of mouth temperature always occurred, while the rectal temperature remained stationary or fell slightly. The 
average difference was usually reduced from $1^{\circ}$ or $1^{\circ} \cdot 5 \mathrm{~F}$. to $0^{\circ} \cdot 3$ or $0^{\circ} .7$ F. $\left(0^{\circ} \cdot 54-83^{\circ}\right.$ C. to $0^{\circ} \cdot 17-0^{\circ} \cdot 38$ C.). After the first fifteen minutes the two ran closely parallel, though towards the end of three hours the rectal temperature usually began to rise faster than that of the mouth. On leaving the room the cool surroundings caused both (especially the mouth temperature) to fall very rapidly.

As has been shown by Haldane, $1905\left(^{9}\right)$, the difference in the behaviour of the two temperatures is due to the fact that the loss of heat from the skin by sweating is largely prevented by the hot moist air, so that the external cool region of the body tends to disappear. The surface temperature of the skin (observed over the precordium and the forehead) was observed to rise from $35^{\circ} \mathrm{C}$. anci $37^{\circ} \cdot 5$ C. or more $\left(95^{\circ}\right.$ to $99^{\circ} \cdot 5 \mathrm{~F}$.).

The subject of the present experiment practically accommodated at an external wet-bulb temperature of below $32^{\circ} \cdot 5 \mathrm{C} .\left(90^{\circ} \cdot 5 \mathrm{~F}\right.$.), only a very gradual rise of rectal temperature occurring at this temperature. The approximate rate of rise of temperature ouce compensation was overcome in a wet-bulb temperature of $35^{\circ} \mathrm{C}$. $\left(95^{\circ}\right.$ F.) (average) was $0^{\circ} \cdot 7$ F. $\left(0^{\circ} \cdot 4\right.$ C.) in the first hour; $1^{\circ} \cdot 2 \mathrm{~F}$. $\left(0^{\circ} \cdot 66 \mathrm{C}\right.$.) in the second; $1^{\circ} \cdot 5 \mathrm{~F} .\left(0^{\circ} \cdot 83 \mathrm{C}\right.$.) in the third (averages). It is interesting to compare this with the statement of Rübner $\left(1895^{11}\right)$, that the normal temperature (dry bulb) between the clothing and the skin is $32^{\circ} \cdot 6 \mathrm{C}$. $\left(90^{\circ} .7 \mathrm{~F}\right.$.), as showing the importance of the humidity of the air. The pulse (radial) with increase of body temperature became more frequent, and of larger volume and higher tension. An average increase of 14 heats per degree F. ( 25 beats per degree $C$. was noted while sitting), the rapidity of increase being greater towards the end of each experiment. Change from the reclining to the standing posture caused an immediate jump in rate, e.g. in one case from 120 to 156 , the pulse for some minutes being almost running and a feeling of dizziness being experienced.

Rising from the chair early in the experiment was associated with marked pulsation in the ears and head. Later on this sensation did not make itself so evident on change of posture, and the pulse was more frequent.

The respirations also became more frequent with rise of temperature, increasing in rate from 10 to 12 up to 20 to 25 per minute, i.e. about 3 per degree F. (5 to 6 per degree C.). Depth and energy increased, though breathing never became distressed or panting.

Sweating was extremely profuse-saturating the flannels worn, and in one experiment the thick felt soles of a pair of shoes. Much irritation resulted from the sodden condition of these garments and from the damp condition of the face, from which, especially with definite rise of internal temperature, the perspiration poured off in big drops.

The results of the experiments are embodied in the charts and 
plates (Plates VII.-X. Figs. 2-7), which show the mouth and rectal temperatures, and also the wet-bulb air temperatures in centigrade and Fahrenheit degrees, together with the respiratory gases in cubic centimetres per minute, at varying intervals during the experiment.

TABLE I.-Combined T'able of the Series, showing Wet-Bulb Temperatures, Respiratory Exchange, and Rectal Temperatures, with Duration of Experiment and Percentage Rises.

\begin{tabular}{|c|c|c|c|c|c|c|c|c|c|c|c|c|c|c|}
\hline & \multirow[b]{2}{*}{ Date. } & \multirow{2}{*}{ 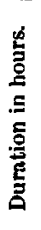 } & \multirow[b]{2}{*}{$\begin{array}{l}\text { Wet BuJb, } \\
\text { Centigrade. }\end{array}$} & \multicolumn{4}{|c|}{ At the Beginning. } & \multicolumn{4}{|c|}{$\begin{array}{l}\text { At the End of the } \\
\text { Experiment. }\end{array}$} & \multirow{2}{*}{ 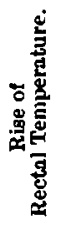 } & \multirow{2}{*}{$\begin{array}{l}\mathrm{CO}_{2} . \\
\text { Tota } \\
\text { cent. }\end{array}$} & \multirow{2}{*}{$\begin{array}{l}\mathrm{O}_{2 .} \text {. } \\
\text { per } \\
\text { iise. }\end{array}$} \\
\hline & & & & $\begin{array}{l}\text { Co. } \\
\text { min } \\
\text { min }\end{array}$ & $\begin{array}{l}\text { per } \\
\text { te. }\end{array}$ & R.Q. & 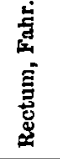 & $\mathrm{CO}$. & $\mathrm{o}_{2}$ & R.Q. & 宸 & & & \\
\hline (1) & June 2, 1907 & 17 & $33^{a}-33^{\circ} \cdot 5$ & 262 & 359 & $0 \cdot 72$ & $89^{\circ .5}$ & 398 & 396 & 0.85 & $100^{\circ} \cdot 2$ & $0^{0.7}$ & 29 & 10 \\
\hline (2) & June 8, " & 4 & $32^{\circ} \cdot 5-35^{\circ}$ & 270 & 329 & 0.82 & $98^{\circ} \cdot 8$ & 402 & 446 & 0.90 & $102^{\circ} \cdot 4$ & $3^{0.6}$ & 49 & 35 \\
\hline (3) & Jujy 13, , & 4 & $35^{\circ}-36^{\circ}$ & 211 & 300 & 0.71 & $98^{\circ} \cdot 6$ & 554 & 585 & 0.98 & $103^{\circ} \cdot 2$ & $4^{\circ} \cdot 6$ & 163 & 98 \\
\hline (4) & July 17, ," & $4 t$ & $34^{0} \cdot 5-35^{\circ}$ & 105 & 288 & $0-73$ & $98^{n} \cdot 9$ & 397 & 457 & 0.87 & $103^{3} \cdot 2$ & $4^{0} \cdot 2$ & 103 & 70 \\
\hline (5) & July 20, " & 8 & $35^{\circ}-36^{\circ}$ & 327 & 415 & 0.79 & $99^{\circ} \cdot 0$ & 483 & 534 & 0.91 & $103^{\circ} \cdot 6$ & $4^{n} \cdot 6$ & 48 & 28 \\
\hline (6) & July 24, , & 41 & $34^{\circ}-36^{\circ}$ & .351 & 421 & $0-83$ & $98^{\circ} \cdot 8$ & 639 & 653 & 0.98 & $103^{\circ} \cdot 3$ & $4^{a} \cdot 5$ & 82 & 55 \\
\hline
\end{tabular}

From these charts and summary it will be seen that rise of rectal temperature, however small, was invariably accompanied by increased respiratory exchange, which, however, varied in amount in the different experiments. Thus in Experiment 3 a rise of $4 \frac{1}{2}^{\circ} \mathrm{F}$. in rectal temperature raised the consumption of oxygen by 98 per cent., while in Experiment 5 the same rise of temperature (rectal) only caused an increase of 28 per cent. in the $\mathrm{O}_{2}$ consumption. It will also be seen that the rise of body temperature was invariably accompanied by a rise in the respiratory quotient.

One of the chief objects aimed at in these experiments has been to imitate, as far as possible, the external conditions which occur in cases of heat-stroke; and so endeavour to effect some closer appreciation of the behaviour of the human body under such circumstances.

Heat-stroke occurs in hot moist climates. The climate need not be very hot in the general meaning of the word-often the temperature does not exceed $90^{\circ} \mathrm{F}$. (dry bulb or ordinary thermometer); the essential factor being the combination of excessive humidity and high temperature. In other words, as Haldane points out $\left(1905^{1}\right.$ ), the wet-bulb reading controls the whole question of the rise of body temperature. Heat-stroke, then, typically occurs where even quite healthy persons are exposed to high wet-bulb temperatures for a 
comparatively few hours. Ill-health, work, and starvation are often contributory causes (Pembrey (1.902 $\left.{ }^{3}\right)$, Zuntz $\left(1896^{18}\right)$ ).

In these experiments the atmospheric conditions shown by a wetbulb reading of $35^{\circ} \mathrm{C}$. (approximately), the long preliminary fasts, and the duration of the exposure to heat of three to five hours, all correspond closely to such climatic conditions. Work was, however, avoided, and a condition of rest observed in order to guard against the considerable increase of metabolism and respiratory gas exchange occasioned by muscular action.

All the experiments point to the fact that once the balance of the mechanism of heat regulation in the human body has been definitely upset by high external temperature, combined with almost total abolition of heat loss in evaporation, a vicious circle is established. The internal temperature rises, and as a result the oxidation processes, and therefore the production of heat also increases, so that the body temperature rises still further, and so on. Once the ball has been set rolling nothing seems to check its progress, and it slowly but surely gathers speed. The rectal temperature not only continues to rise, while the external temperature still remains constant, but the rise gradually increases in rapidity as if momentum were being gathered. No evidence was obtained of any definite attempt at the re-establishment of a balance between heat production and heat loss (excepting in one experiment, No. 6, where the wet-bulb temperature fell to about $32^{\circ} \cdot 5 \mathrm{C}$.). The whole change in internal temperature and metabolism was progressive from the start. The body in these short experiments showed no power of readjustment with a "higher level" (v. Liebermeister $\left({ }^{13}\right)$ ) of body temperature.

It would appear, then, that in heat-stroke or rapid overheating the only chance of obtaining a fall in internal temperature is by removal to more favourable surroundings, where increased evaporation, or greater loss of heat by radiation and conduction, or both, will again approximate the two sides of the balance sheet-heat production and heat loss. The energetic reduction of the (internal) body temperature must therefore be the essential aim of treatment; for besides being at the root of the whole condition-metabolic, circulatory, respiratory, and nervous phenomena-the changes in the body temperature have a distinct tendency to be progressive. Even at the present day cases continually crop up in practice where this principle of treatment has been neglected and jurely drug treatment (strychnine, etc.) relied on, with fatal consequences to the patient.

\section{Denuctions from Experiments as to the Effect of Overheating on Metabolism.}

The observation of the respiratory exchange and quotient is the only method which affords us any real idea of the changes of metabolism in experiments of only a few hours' duration. 
TABLE II.-Respiratory Exchange (combined Data from the Experiments).

\begin{tabular}{|c|c|c|c|c|c|c|c|c|c|c|c|}
\hline & \multirow{2}{*}{ Wet Bulb. } & \multicolumn{3}{|c|}{ At the Beginning. } & \multicolumn{3}{|c|}{$\begin{array}{l}\text { At the End of } \\
\text { Heating. }\end{array}$} & \multicolumn{3}{|c|}{ After Experiment. } & \multirow{2}{*}{$\begin{array}{l}\text { Time } \\
\text { after. }\end{array}$} \\
\hline & & $\frac{\mathrm{CO}_{2}}{\mathrm{O}_{2}}$ & R.Q. & $\begin{array}{c}\text { Rectal } \\
\text { Temper. } \\
\text { ature. }\end{array}$ & $\begin{array}{l}\mathrm{CO}_{2} \\
\mathrm{O}_{2}\end{array}$ & R.Q. & Rectum. & $\frac{\mathrm{CO}_{2}}{\mathrm{O}_{2}}$ & R.Q. & $\begin{array}{l}\text { Rec. } \\
\text { tum. }\end{array}$ & \\
\hline (1) & $33^{\circ}-33^{\circ} \cdot 5 \mathrm{C}$ & 389 & 0.72 & $99^{\circ} \cdot 5 \mathrm{~F}$ & $\frac{3}{3} \frac{38}{6}$ & 0.85 & $100^{\circ} \cdot 2 \mathrm{~F}$ & ... & $\cdots$ & $\cdots$ & $\ldots$ \\
\hline (2) & $32^{\circ} \cdot 5-35^{\circ}$, & $\frac{97}{3} \frac{8}{8}$ & 0.82 & $98^{\circ} \cdot 8$, & 182 & 0.90 & $102^{\circ} \cdot 4$, & ... & $\cdots$ & $\cdots$ & $\cdots$ \\
\hline (3) & $35^{\circ}-36^{\circ}$ & $3 \frac{1}{60}$ & 0.71 & $98^{\circ} \cdot 6$, & $\frac{5}{5} \frac{5}{6}$ & 0.93 & $103^{\circ} \cdot 2$, & $4 \xi 2$ & 0.89 & $100 \cdot 9$ & $\frac{1}{2}$ hour \\
\hline (4) & $34^{\circ} \cdot 5-35^{\circ}$, & $\frac{1}{2} \frac{95}{8}$ & 0.73 & $98^{\circ} \cdot 9$, & $\frac{397}{687}$ & 0.87 & $103^{\circ} \cdot 2$, & $\frac{3}{37} \frac{2}{8}$ & 0.87 & $100 \cdot 2$ & \\
\hline (5) & $35^{\circ}-36^{\circ} \quad$ & $\frac{3}{6} 3^{2} \frac{7}{6}$ & 0.79 & $99^{\circ} \cdot 0$, & 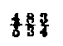 & 0.91 & $103^{\circ} \cdot 6$, & $45 \frac{9}{1}$ & 0.89 & $102 \cdot 6$ & 光, \\
\hline (6) & $34^{\circ}-36^{\circ} \quad$, & $3^{8} \frac{1}{1}$ & 0.83 & $98^{\circ} \cdot 8$, & $\frac{8}{8} 8 \frac{9}{3}$ & 0.98 & $103^{\circ} \cdot 3$, & $\cdots$ & $\cdots$ & $\cdots$ & .. \\
\hline \multicolumn{12}{|c|}{$\mathrm{CO}_{2}$ AND $\mathrm{O}_{2}$ IN c.c. PER MINUTE. } \\
\hline \multicolumn{2}{|c|}{$\left.\begin{array}{l}\text { Average- } \\
34^{\circ}-35^{\circ} \mathrm{C} .\end{array}\right\}$} & $\frac{9}{3} \frac{9}{4} 8$ & $0 \cdot 77$ & $\left(\begin{array}{l}98^{\circ} \cdot 9 \mathrm{~F} . \\
\left(37^{\circ} \cdot 1 \mathrm{C} .\right)\end{array}\right)$ & $\frac{4}{3} \frac{9}{2}$ & 0.916 & $\mid \begin{array}{l}102^{\circ} 65 \mathrm{~F} \\
\left(39^{\circ} .2 \mathrm{C} .\right)\end{array}$ & $\cdots \cdots$ & $\ldots \ldots$ & $\ldots \cdots$ & $\ldots \cdots$ \\
\hline
\end{tabular}

TABLE III.-Expression of these Averages in terms of Food Stuffs according to Rübner's Values.

\begin{tabular}{|c|c|c|c|c|c|c|c|c|c|}
\hline & Protein. & Fat. & $\begin{array}{l}\text { Carbo- } \\
\text { hydrate. }\end{array}$ & & & Protein. & Fat. & $\begin{array}{l}\text { Carbo- } \\
\text { hydrate. }\end{array}$ & \\
\hline R.Q. $0.77=(i)$ & 0 & 80 & 20 & & R. Q. $0 \cdot 916^{\circ}=(i)$ & 0 & 30 & 70 & \\
\hline \multirow[t]{2}{*}{ or (ii) } & 15 & 70 & 15 & $=\mathbf{A}$ & or (ii) & 15 & 19 & 66 & $=B$ \\
\hline & & & & & or (iii) & 30 & 0 & 73 & $=\mathrm{C}$ \\
\hline
\end{tabular}

The following now shows the cubic centimetres of respiratory gases concerned in the metabolism of protein and non-nitrogenous bodiesfats and carbohydrates-respectively for the R.Q.s given. (C is the value for 0.916 , if we allow for doubling of protein metabolism.)

TABLe IV.

\begin{tabular}{|c|c|c|c|c|c|c|}
\hline & \multicolumn{6}{|c|}{ Value. } \\
\hline & \multicolumn{2}{|c|}{ A. } & \multicolumn{2}{|c|}{ B. } & \multicolumn{2}{|c|}{ c. } \\
\hline $\begin{array}{l}\text { Total respiratory exchange } \\
\text { Protein }=7.16 \times 6.25\end{array}$ & 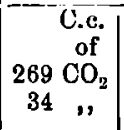 & $\begin{array}{r}\text { C.c. } \\
\text { of } \\
348 \mathrm{O}_{2} \\
43\end{array}$ & $\begin{array}{r}\text { C.c. } \\
\text { of } \\
469 \mathrm{CO}_{2} \\
34 \quad "\end{array}$ & $\begin{array}{c}\text { C.c. } \\
\text { of } \\
512 \mathrm{O}_{2} \\
43\end{array}$ & $\begin{array}{r}\text { C.c. } \\
\text { of } \\
460 \mathrm{CO}_{2} \\
69 " \Rightarrow\end{array}$ & $\begin{array}{r}\text { C.c. } \\
\text { of } \\
512 \quad \mathrm{O}_{2} \\
87 \quad,\end{array}$ \\
\hline $\begin{array}{l}\text { Difference }=\text { Amount used up of } \\
\text { non-nitrogenous food }\end{array}$ & $235 \mathrm{CO}_{2}$ & $305 \mathrm{O}_{2}$ & $435 \mathrm{CO}_{2}$ & $469 O_{2}$ & $400 \mathrm{CO}_{2}$ & $425 \mathrm{O}_{2}$ \\
\hline
\end{tabular}


From the Equation $x=\mathrm{O}_{2}$ in c.c. for Fat.

$$
\begin{aligned}
& 3 \frac{3}{3}-0.71 x+(305-x)=235=\text { Fat } \frac{7}{7} \frac{7}{7} \frac{1}{2} \text { carbohydrate } \frac{6}{6} \frac{4}{4} \text {. }
\end{aligned}
$$

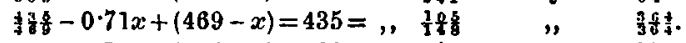

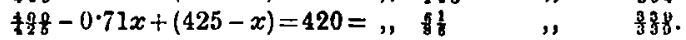

$=$ Rise of five to six times in amount of carbohydrate consumed.

NorE.-These calculations, it is true, ignore the possibility that the increased respiratory quotient may be due to increased liberation of preformed $\mathrm{CO}_{3}$ owing to such causes as rise of body temperature itself and diminished alkalinity of the blood and tissues, and finally decreased percentage of alveolar carbon dioxide. No definite evidence regarding these points has been obtained.

These tables, and calculations from them, have been based on Riibner's $\left(1902^{10}\right)$ carefully estimated values for the different food stuff's. He gives the respiratory quotients for proteid, fat, and carbohydrate as $0.809,0.7069$, and 1.00 respectively. Following these up, and comparing them with the average results from our series of experiments, we see that a rise of quotient from 0.77 to 0.916 is equivalent to an increase of carbohydrate consumption to five to six times its previous amount; and this, even where we allow for an increased proteid destruction of twice the normal amount (C), - a far greater rise than any observed, even where the rise of temperature in the overheating experiment exceeded $2^{\circ} \cdot 65 \mathrm{~F} .\left({ }^{7}\right)$.

The carbohydrates, therefore, are the first to be sacrificed when the body loses its power of compensation for heat and its internal temperature rises. And, though previous investigators vary as to this point-Winternitz $\left(1899^{6}\right)$ and Rübner $\left(1902^{10}\right)$ only record a small increase, Linser and Schmid $\left({ }^{7}\right)$ actually a fall-sufficient care was not exercised by them to eliminate the effect of previous meals, which may mask the above-mentioned rise of quotient.

As to the relationship to the increased secretion of nitrogen observed in rise of temperature (Ringer, etc.), Linser and Schmid $\left(^{7}\right)$ deny any such rise before the temperature reaches $104^{\circ} \mathrm{F}$. (approximately).

At any rate, in the early stages of heat-stroke and overheating it is quite dwarfed by the carbohydrate consumption. This agrees with the well-established value of non-nitrogenous material in limiting the destruction of protein.

With regard to high temperature effects, Hirsch and Rolly ( ${ }^{22}$ ) long ago showed a destruction of glycogen in febrile processes. Senator and Richter denied this direct relationship of glycogen destruction to rise of temperature, but nevertheless suggested that increased nitrogenous output is not nearly so often met with as increased heat production, and hence that overheating means an increased consumption of non-nitrogenous material. Overberg (Voit) found a dearth of glycogen in the liver of animals after overheating, and by giving carbohydrate (sugar 30 to 40 grms.), succeeded in preventing excessive nitrogenous excretion. Linser and Schmid ( ${ }^{7}$ ) deny that this power is as marked in high body temperature as in the 
healthy or normal condition, still their results point to a certain increase of non-nitrogenous katabolism.

High temperatures due to cerebral puncture are associated with a disappearance of glycogen from the liver.

That carbohydrates may have an even deeper part to play in the resistance of the body to overheating is suggested by many facts, such as the devotion of tropical natives to a carbohydrate diet, e.g. rice, the percentage of nitrogen in their diet being very low.

Robin and Binet's observations $\left(1896^{12}\right)$ in typhoid are also suggestive regarding this. They concluded that the respiratory quotient varied inversely as the gravity of the illness, and that the last effort of resistance is greater $\mathrm{CO}_{2}$ production and ventilation, the respiratory quotient rising though the oxygen requirement is lessened.

In conclusion, the experiments show that in the human subject the rise of the internal temperature, due to high external temperature of the body is accompanied by-

(1) Marked rise in the total respiratory exchange; (2) a decided rise in the respiratory quotient, pointing probably to (3) a greatly increased consumption of carbohydrate material.

ADDENDUM.

Winternitz's Table (6) modified.

\begin{tabular}{|c|c|c|c|c|c|c|c|c|}
\hline \multirow[b]{2}{*}{ Date. } & \multicolumn{3}{|c|}{$\begin{array}{c}\text { At the End of the Hot } \\
\text { Bath. }\end{array}$} & \multirow[b]{2}{*}{$\begin{array}{l}\text { Duration } \\
\text { of Bath. }\end{array}$} & \multicolumn{3}{|c|}{$\begin{array}{l}\text { Some Time after the } \\
\text { Bath. }\end{array}$} & \multirow[b]{2}{*}{ Remarks. } \\
\hline & 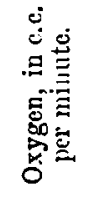 & 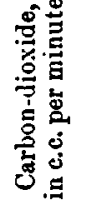 & R.Q. & & 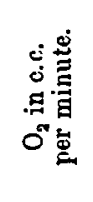 & 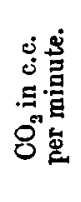 & R.Q. & \\
\hline Normal & 176.8 & $138 \cdot 5$ & $0 \% 8$ & $\begin{array}{c}\text { Minutes. } \\
\quad \ldots\end{array}$ & ... & $\cdots$ & $\cdots$ & $\begin{array}{c}\text { Minutes after. } \\
\quad \ldots\end{array}$ \\
\hline 11th & $322 \cdot 9$ & 243 & 0.73 & 47 & $204 \cdot 4$ & $151 \cdot 4$ & 0.74 & 48 \\
\hline 15 th & 318 & $272 \cdot 5$ & 0.85 & 23 & $182 \cdot 9$ & $151 \cdot 1$ & 0.82 & 45 \\
\hline 18th & $363^{\circ} 6$ & $316 \cdot 2$ & 0.86 & 35 & $\left\{\begin{array}{l}207 \cdot 9 \\
193 \cdot 3\end{array}\right.$ & $\begin{array}{l}156 \cdot 7 \\
143.8\end{array}$ & $\begin{array}{l}0.75 \\
0.74\end{array}$ & $\begin{array}{l}45 \\
75\end{array}$ \\
\hline 25 th & $\left\{\begin{array}{l}248 \cdot 7 \\
292\end{array}\right.$ & $\begin{array}{l}214 \cdot 2 \\
251 \cdot 3\end{array}$ & $\begin{array}{l}0.86 \\
0.86\end{array}$ & $\left.\begin{array}{l}23 \\
48\end{array}\right\}$ & 225 & $168 \cdot 2$ & 0.74 & 30 \\
\hline 29th & $\left\{\begin{array}{l}283 \\
321 \cdot 2\end{array}\right.$ & $\begin{array}{l}231 \cdot 6 \\
282 \cdot 4\end{array}$ & $\begin{array}{l}0.81 \\
0.87\end{array}$ & $\begin{array}{l}20 \\
45\end{array}$ & $\begin{array}{l}197 \cdot 9 \\
215 \cdot 5\end{array}$ & $\begin{array}{l}149 \cdot 2 \\
164 \cdot 1\end{array}$ & $\begin{array}{l}0.75 \\
0.76\end{array}$ & $\begin{array}{l}45 \\
78\end{array}$ \\
\hline
\end{tabular}

The adoption of a "normal" as a basis of calculation for experiments conducted on different days is fallacious. 
With the exception of the first (11th), Winternitz's results show a high respiratory quotient $(0.85$ approximately), and increase in respiratory exchange at the end of the overheating; and also a drop in the respiratory exchange and a fall of respiratory quotient ( 0.75 approximately) some little time after the end of the bath, when the internal temperature previously raised by overheating was resuming its ordinary level. If, as seems justifiable, we can regard the rectal temperature as definitely raised by the hot bath, and lowered again in the cool, the figures given directly confirm my own results.

My deepest thanks are due to Dr. J. S. Haldane, Reader in Physiology, Oxford University, for much kindly advice and encouragement, without whose aid these investigations would have been inpossible.

\section{REFERENCES.}

1. Haldane . . . . . . Journ. Hyg., Cambridge, 1905, vol. v. p. 494.

2. Rogers, Leonard . . . Royal Army Medical Corps Journ., London, 1908 , vol. x. p. 25.

3. Pembrey . . . . . . Guy'sHosp. Rep.,London,1902, vol. Ivii. p. 283.

4. Sambon . . . . . . Brit. Med. Journ., London, 1898, vol. i. p. 744.

5. Pflüger (and Pupils) . . Arch.f.d. Ges. Plyysiol., Bonn, 1877, Bd. xiv. ; 1882 , Bde. xxix., xxxii.

6. Winternitz . . . . . Klin. Jahrb., Berlin, 1899, Bd. vii. S. 299.

7. Linser u. Schmid . . . Deutsches Arch. f. Klin. Med., Leipzig, Id. xxix. S. 514.

8. Pembrey and Spriggs. - Jouru. Physicl., Cambridge and London, 1904, vol. xxxi. p. 320 .

9. Haldane axd Priestiey . Ilid., 1905, vol. xxxii. p. 225.

10. Rubser . . . . . . "Die Gesetze des Energieverbrauchs bei der Ernïhrung," Leipzig, 1902.

11 .

Arch.f. Hyg., München u. Leipzig, 1895, Bu. xxiii. S. 13.

12. RoBIN et BINET

"Études cliniques sur le chinisme respiratoire," Arch. gén. de méd., Paris, 1896, tome ij. p. 385.

Also consulted.

13. v. Liebermeister . . . "Handbuch d. Path. u. Therap. d. Fiebers," Leipzig, 1875, S. 84 .

14. WELCH . . . . . . "Cartwright Lectures on Fever," New Yor. Med. Jour'n., 1888, p. 365.

15. Burdos-Sanderson . . Allbutt and Rolleston, "System of Medicine," 1905, vol. i. p. 818. (Historical Retrospect.)

16. Pembrey . . . . . . In Schiffer's "Text-Book of Physiology," Edin. and London, 1898, vol. i. p. 692.

18. ZuNrz . . . . . . . Berl. Klin. Wchnschr., 1896 (Hitzschlag), Bd. xxxii. S. 709.

19. Zuntz u. Schumburg . . " Physiol. des Marsches," Berlin, 1901.

20. Loewy u. Zunjz . . . Arch. f. Anat. u. Physiol. (Physiol. Abth.), Leipzig, 1904, S. 166.

21. Langlors . . . . . . Richet, "Dict. de Physiol.," Paris, 1904, tome vi., art. "Fièvre."

22. KREHL

"Lehrbuch d. Path. Physiol.," 3te Aufl., Leipzig, 1904.

23. Von Noorden . . . "Pathology of Metabolism," "Fever" (F. Kraus), 1907. 
FIQ. 1.

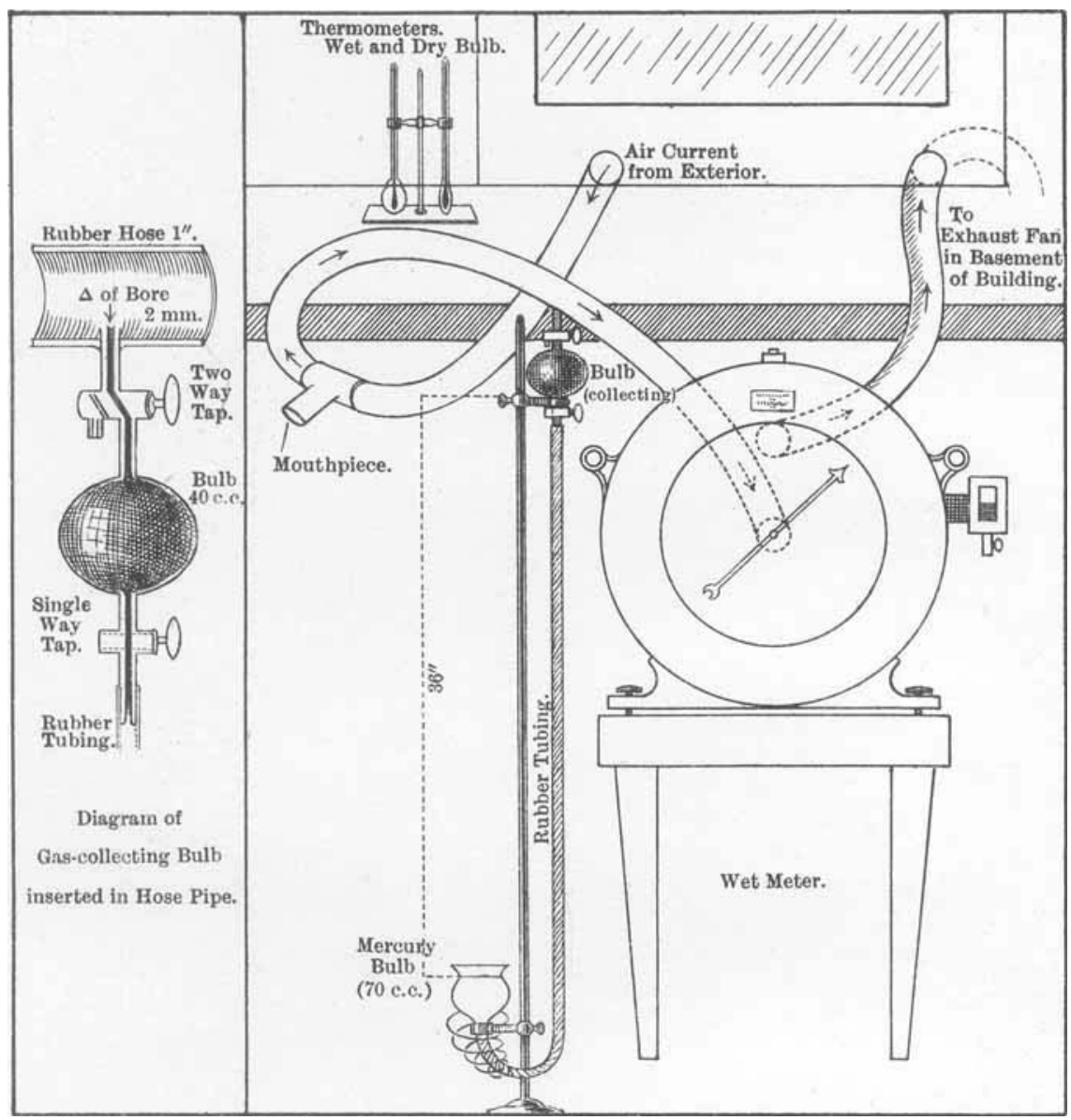

The Haldane Apparatus tor obtaining the Respiratory Exchange, modified trom the method of zantz. 


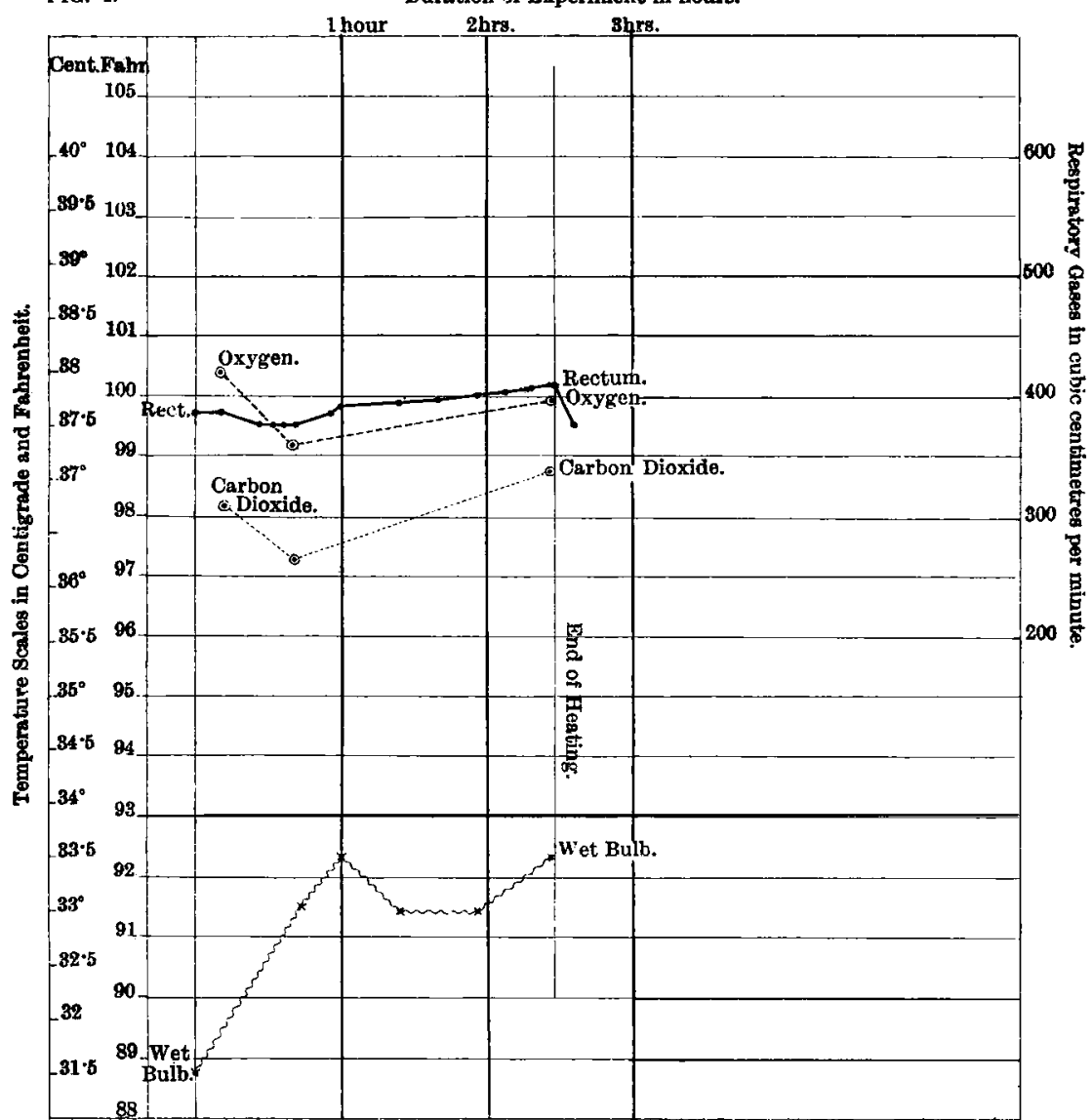

Thick continuous line, Rectal $\}$ Mouth Temperatures. Thick dotted lines, Oxygen.

Thin ", " $\left.\quad \begin{array}{l}\text { Mouth } \\ \text { Wet Bulb }\end{array}\right\}$ Temperatures. Thin " " $\mathrm{OO}_{2}$ in c.c. per minute.

EXPERIMENT $2(8 / 6 / 07)$.

FIG. 3.

Duration of Experiment in hours.

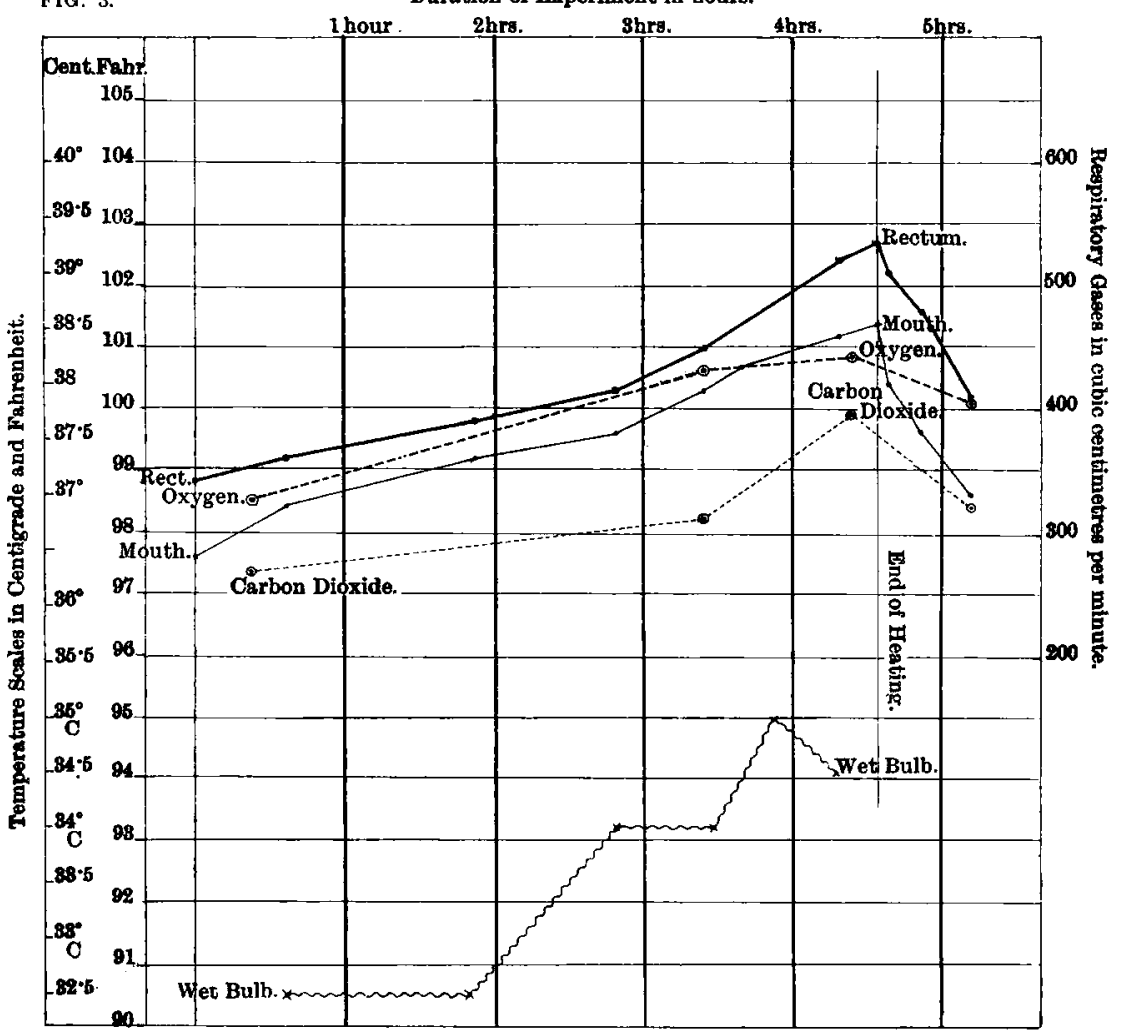


FIa. 4.

Durstion of Experiment in hours.

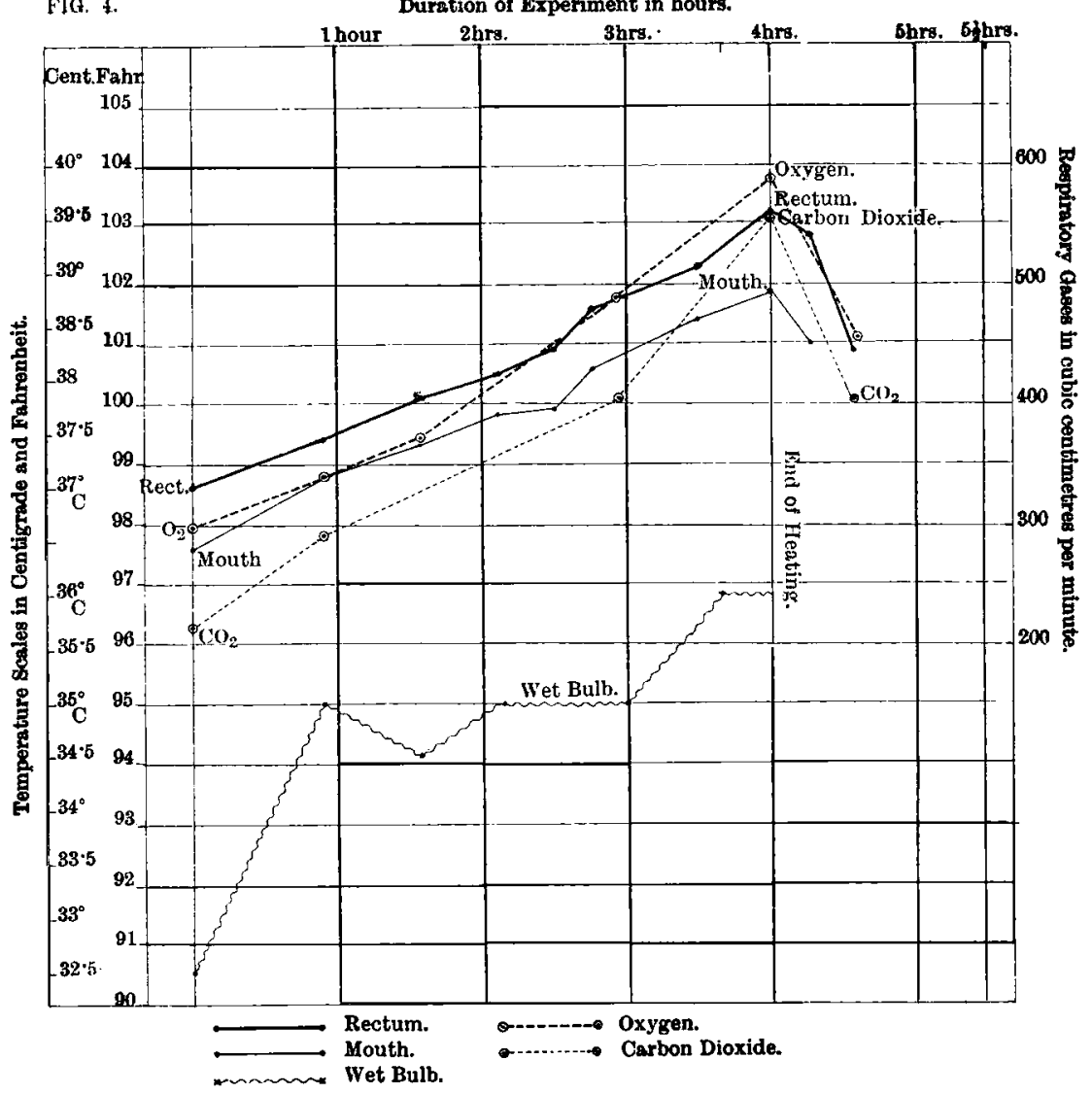

EXPERIMENT 4 (17/7/07).

FIG. 5.

Duration of Experiment in hours.

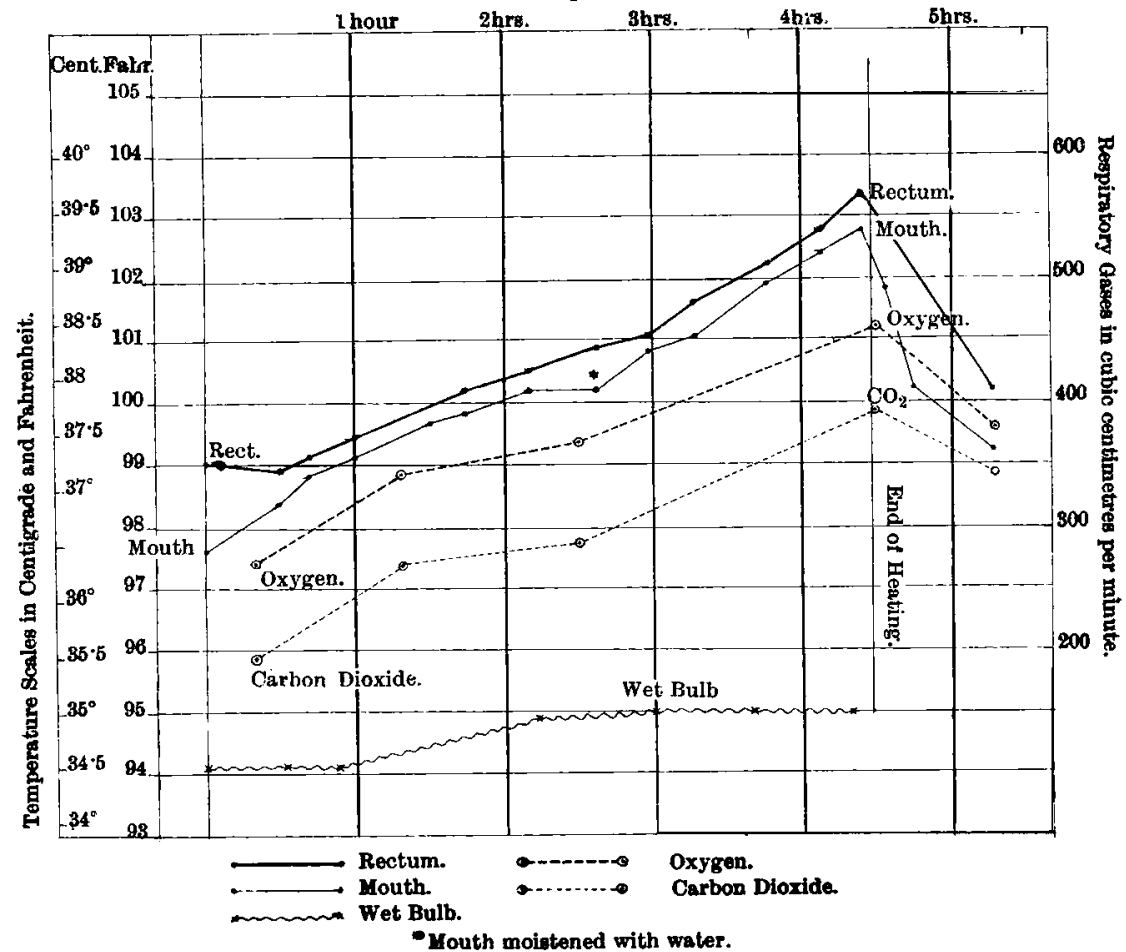




\section{EXPERIMENT $5(22 / 7 / 07)$}

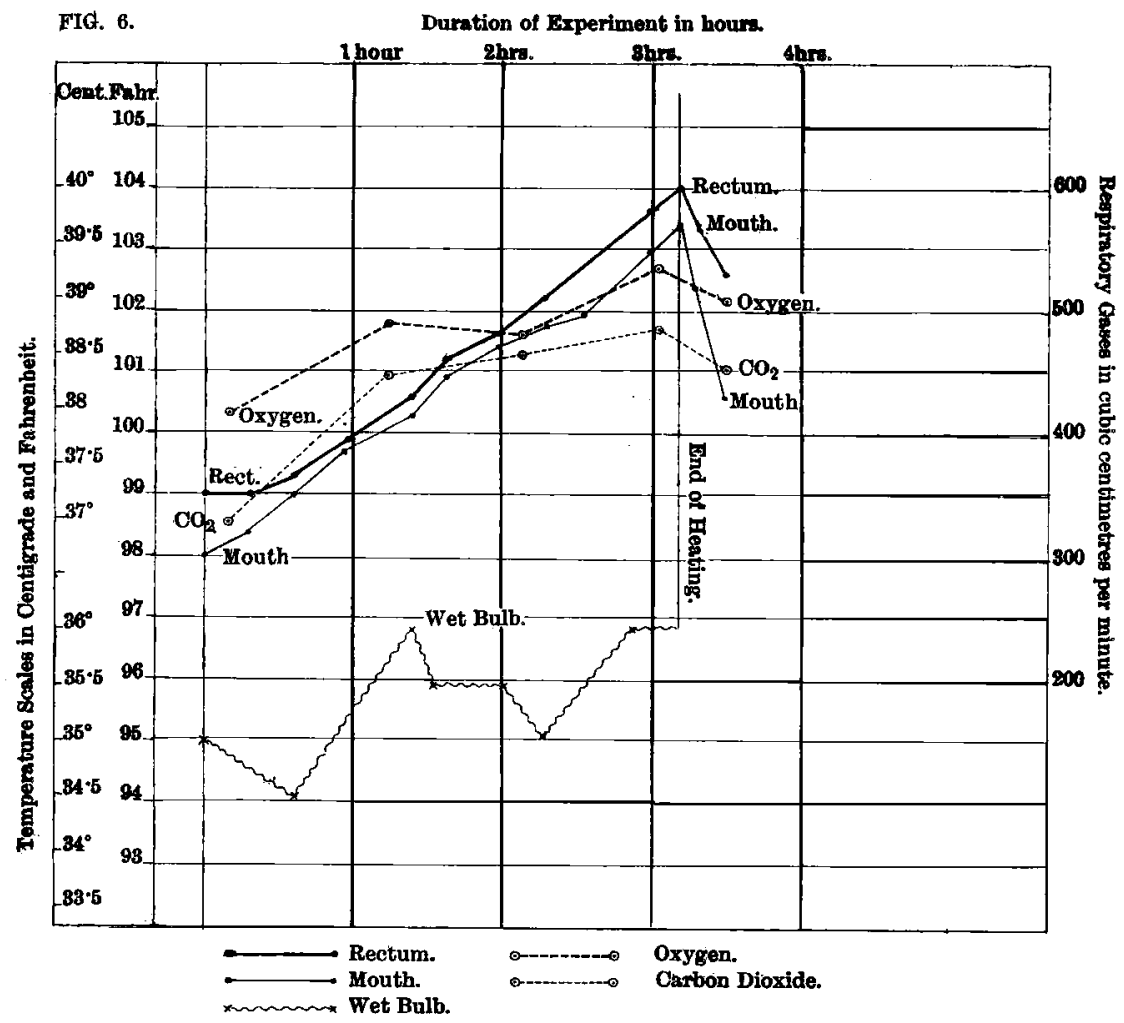

EXPERIMENT $6(24 / 7 / 07)$.

FIG. 7.

Duration of Experiment in hours.

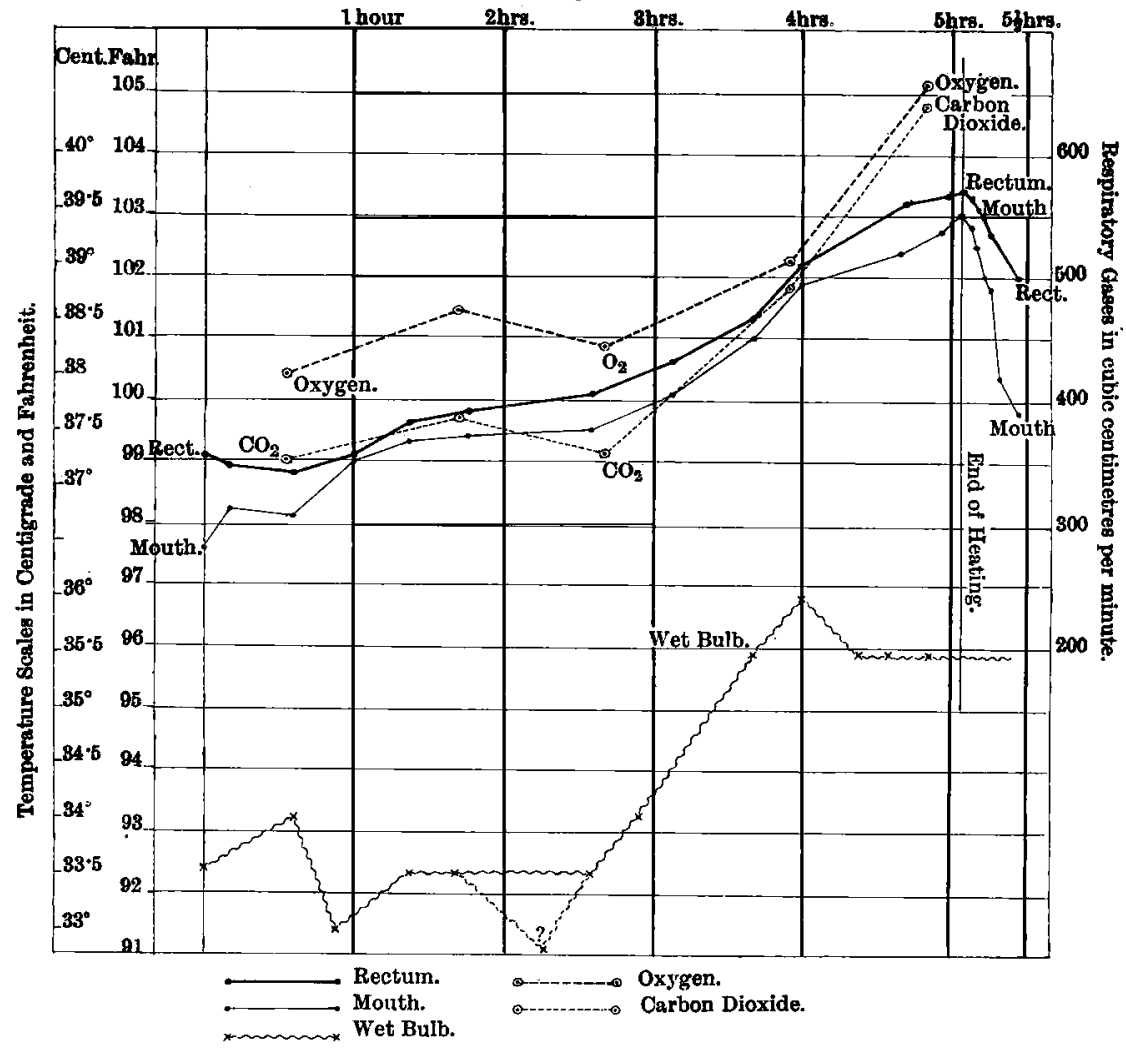




\section{DESCRIPTION OF PLATES VII.-X.}

Plate VII.

FIG. 1.-The Haldane apparatus for obtaining the respiratory exchange, modified from the method of Zuntz.

Plate Vill.

Fic. 2.-Record of Experiment 1.

FrG. 3.-Record of Experiment 2.

Plate IX.

Fia. 4.-Record of Experiment 3.

Fig. 5.-Record of Experiment 4.

Plate X.

Fig. 6.-Record of Experiment 5.

FIG. 7.-Record of Experiment 6. 